\title{
オフイスビルのエレベータバンク構成に関する数理モデル ーコンベンショナルゾーニング方式のための最適設計一
}

A MATHEMATICAL MODEL ON DESIGN OF BANKS OF ELEVATORS IN THE OFFICE BUILDING

-Optimal design for conventional zoning system-

黒澤＼cjkstart俊*, 栗田＼cjkstart治**

Shun KUROSAWA and Osamu KURITA

\begin{abstract}
In this thesis we search for the optimal height of office building and the optimal design of banks of elevators from two viewpoints in the case that the conventional zoning system is adopted: 1) to maximize dwelling area of office building and 2) to maximize profit by constructing office building. The main results are as follows: i ) it was shown that the best design of banks of elevators which had been obtained by the model was almost corresponding to those in existing multistory office buildings; ii ) it was shown that if we make office building higher too much the dwelling area of the building does decrease.
\end{abstract}

\section{Keywords : office building, design of banks of elevators, conventional zoning system, dwelling area of office building, profit by constructing office building オフィスビル, エレベータバンク構成，コンベンショナルゾーニング方式, ビルの有効容積, ビル建設による利潤}

\section{1. はじめに}

人口や諸機能の大都市への集中は都市の高層化をもたらし，これ に呼応して高層ビルに関する様々な議論が為されてきた．奥平[1] はオフィスビルに発生する通勤交通を滞りなく通過させることを想 定し, ビルの居住可能な部分の容積(以後有効容積と呼ぶ), 鈶直方 向の移動手段であるエレベータの通路面積, そしてエレベータの輸 送力を用いた明解なモデル提案した. そしてビルを過度に高層化 してゆくとビルの有効容積は増加すれども頭打ちになってしまうこ とを都市解析学の立場から示した。

本研究では, 現実の高層ビルのエレベータ計画において定番とな っているコンベンショナルゾーニング方式(文献[2]参照)に焦点を䋏 り，数理計画的な観点からその特性を明らかにする．ここで言うコ ンベンショナルソーニング方式とは, 例えば群 A のエレベータはビ ルの 1 階ならびに 2 階から 10 階に停り, 群 B のエレベータはビル の 1 階ならびに 11 階から 20 階に停る, といった具合にエレベータ が特定の階のみにサービスを行なう輸送方式である，また，エレベ 一タの輸送力はエレベータがビル内を往復する所要時間に依存する ものとする. 所要時間が長くなればエレベータが通勤時間帯にビル 内を往復できる回数が少なくなるため，通勤時間帯に通過させるこ とができる人数は減少してしまうのである.
我々のモデルが追求するものは, 最適なビルの高さと最適なエレ ベータバンク構成である．これらは高層オフィスビルの計画には欠 かせないものであり，これまで膨大かつ繥密な確率的シミュレーシ ヨンに基づいて議論されてきたものと考えられる. 本研究では, む しろ単純化された（シミュレーションによらない）数理計画モデル を定式化し（2 章)，これによってもある水準の設計指針が導き出せ ることを明らかにしたい．ここで何を以って「最適」とするかについ てであるが，本研究では高首オフィスビルを計画する際に重要視さ

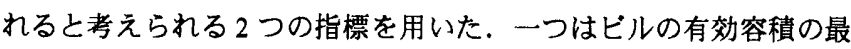
大化であり，もう一つはビル建設による利潤の最大化である.

3 章では, ビルの有効容積を最大化するエレベータバンク構成を 追求する. そして実在する高層オフィスビルの適切性を議論する. 4 章では，ビルの有効容積を最大化するビルの高さを追求する．そこ ではビルを過度に高層化してゆくと，ビルの有効容積が減少に転じ てしまうことが明示される.さらに 5 章では，ビル建設による利潤 を最大化するビル高さを, (1)企業が用地を取得し自社ビルを建設す る場合と，(2)ディベロッパーが自己所有地に儧貸オフィスピルを建 設する場合の 2 つのケースから追求する．そしてオフィスビルの高 層化が経済学的な必然であること, しかし高層化には同時に限界が 存在することを本モデルの立場から記述する。
*キャノン侏 工修

** 慶應義熟大学:大学院理工学研究科 助教授・学博
Canon Inc., M. Eng.

Assoc. Prof., Graduate School of Science and Technology, Keio University, Ph. D. 
2. 定式化

本章ではコンベンショナルソーニング方式のモデル化を行なう.

2.1 ビルとソーニンタ

ビルを高さ $H[\mathrm{~m}]$, 底面皘 $S\left[\mathrm{~m}^{2}\right]$ の直方 体とする， $S$ は所与とし， $H$ は可変であ るものと想定する.そしてビルを図 1 の如 くに $N$ 個の直方体に分割し，これを便宜 上ソーンと名付ける. 更に上から $n$ 番目の ソーンをソーン $n$ と呼び

$$
\begin{array}{r}
h_{n} \quad=(\text { ソーン } n \text { の高さ }[\mathrm{m}] \\
(1 \leq n \leq N)
\end{array}
$$

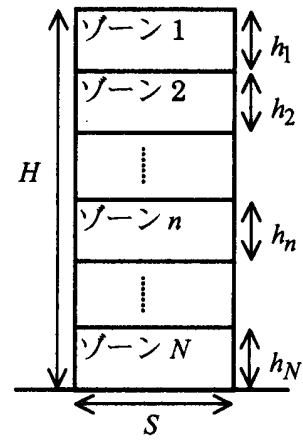

と定義する.ソーンの高さの総和はビルの 高さと一致する：

$$
\sum_{n=1}^{N} h_{n}=H \text {. }
$$

ここでビル内のエレベータを図 2 の如くに配置する. 即ち, エレ ベー夕群 $n(1 \leq n \leq N)$ を構成するエレベー夕(以後群 $n$ のエレベー 夕と呼ぶ)恃地上階とソーン $n$ 内の階のみに停止し, 他のソーンは通 過するのである.

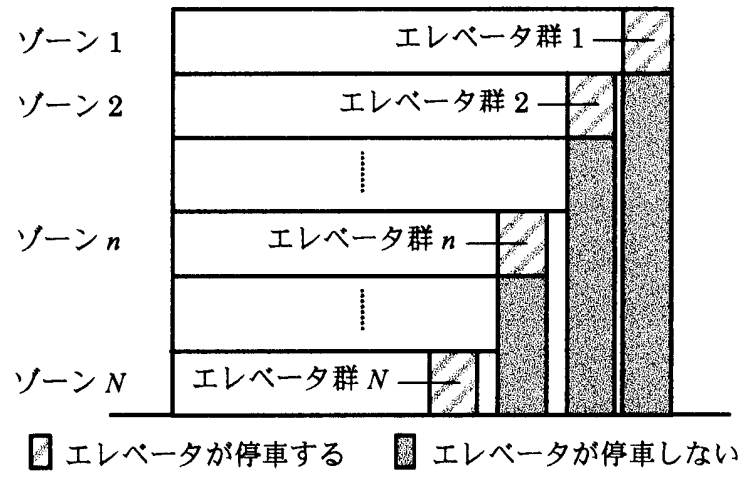

图 2 ビル内のエレベータ.

\section{2 ビルの有効容程}

先ずビル内の就業者の移動に関して次を仮定する：

1 通勤時間帯を想定し, 地上階からビルの各階への移動のみを考慮 する.ビルに発生する内々の移動も考慮した分析には田口[3]がある が，本研究では通勤時間带に発生する地上階からビルの各階への移 動量が膨大であるため，これに対応できるだけの通路を確保してお けば良いという立場に立つことにする.

2 ビル内の鈶直方向の移動手段はエレベータのみとする

3 ビル内の水平方向の移動は考慮しない，水平方向の移動ならびに 移動に要する廊下も考慮した分析には田口[4]があるが, 本研究では ソーニング方式におけるエレベータバンク構成を主題とする.
さらに

$\rho=$ (ビルの居住可能な部分の就業者密度(以後ビルの就 業者密度と呼ぶ) $\left[\right.$ 人 $\left./ \mathrm{m}^{3}\right]$,

$c_{n} \quad=$ (エレペータ群 $n$ の単位面積通路が通勤時間带に通 させることができる人数) $\left[\right.$ 人 $\left./ \mathrm{m}^{2}\right]$,

$L_{n} \quad=$ (ソーンnのエレベータ通路面䅡) $\left[\mathrm{m}^{2}\right]$,

$V_{n} \quad=(ソ-ン n$ の有効容積 $)\left[\mathrm{m}^{3}\right]$,

$V \quad=$ (ビルの有効容積 $)\left[\mathrm{m}^{3}\right]$

を定義し，次に示す奥平[1]の定式化を踏襲する(本モテルは解析学 の枠組みで解を明示することを旨とし， $L_{n}$ を連続量で与えている).

定式化：通勤時間帯に就業者の輸送を完了させるために は, 任意の高さのエレベー夕通路が通勤時間帯に通過させ ることができる人数と, その高さよりも上階に居住する就 業者数とが少なくとも一致していなければならない.

以上より,ソーン $n$ の有効容積と群 $n$ の通路面稙との関係は

$$
\rho h_{n}\left(S-L_{n}\right)=c_{n}\left(L_{n}-L_{n-1}\right) \quad(1 \leq n \leq N)
$$

と記述できる(便宜上 $L_{0}=0$ と定義する). (2)式において, 左辺はビ ルの就業者密度 $\rho\left[人 / \mathrm{m}^{3}\right]$ とソーン $n$ の有効容稙 $h_{n}\left(S-L_{n}\right)\left[\mathrm{m}^{3}\right]$ と の積，即ちソーン $n$ 内の就業者数を表している(図 3 参照). 右辺は エレベー夕群 $n$ の単位面積通路が通勤時間帯に通過させることが できる人数 $c_{n}\left[\right.$ 人 $\left./ \mathrm{m}^{2}\right]$ とエレベータ群 $n$ の通路面皘 $L_{n}-L_{n-1}\left[\mathrm{~m}^{2}\right]$ と の積, 即ちエレベー夕群 $n$ が通勤時間帯に通過させることができる 人数を表している(図 3 参照)、この漸化式を解くと

$$
L_{n}=S\left(1-\prod_{k=1}^{n} \frac{c_{k}}{\rho h_{k}+c_{k}}\right) \quad(1 \leq n \leq N)
$$

が得られる.よってソーン $n$ の有効容積 $V_{n}\left[\mathrm{~m}^{3}\right]$ ならびにビル全体で の有効容積 $V\left[\mathrm{~m}^{3}\right]$ は次の如くに算出される：

$$
V_{n}=h_{n}\left(S-L_{n}\right)=S h_{n} \prod_{k=1}^{n} \frac{c_{k}}{\rho h_{k}+c_{k}}
$$

$$
(1 \leq n \leq N),
$$

$$
V=\sum_{n=1}^{N} V_{n}=S \sum_{n=1}^{N} h_{n} \prod_{k=1}^{n} \frac{c_{k}}{\rho h_{k}+c_{k}}
$$

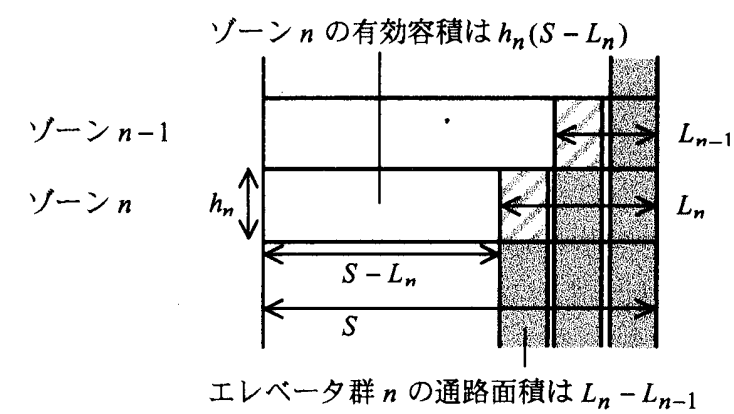

図 3 ソーン $n$ の有効容程とエレベー夕群 $n$ の通路面䅡. 


\section{3 エレベータの輸送カ}

エレペータ群 $n$ の単位面皘通路が通勤時間帯に通過させること ができる人数 $c_{n}\left[\right.$ 人 $\left./ \mathrm{m}^{2}\right]$ を記述する. 先ずビル内のエレベータの運 行に関して次を仮定する：

1 エレベータがビル内を往復する(地上階を出発し地上階に戻って くる)所要時間は一定とする.そしてその所要時間はエレベータ群こ とで異なるとする，長い距離を往復しなければならないエレベータ ほど所要時間は長くなるのである.

以上より, エレベータ群 $n$ の単位面積通路が通勤時間帯に通過さ せることができる人数 $c_{n}\left[\right.$ 人 $\left./ \mathrm{m}^{2}\right]$ は, 単位面積のエレベー夕通路に 乗車できる人数と, 群 $n$ のエレベータが通勤時間帯にビル内を往復 する回数との積で記述できる．具体的に

$\lambda=$ (単位面積のエレベータ通路に乗車できる人数 $)$ [人 $/ \mathrm{m}^{2}$ ],

$\tau_{n}=$ (群 $n$ のエレベータがビル内を往復する所要時間) [s],

$T \quad=$ (通勤時間帯) [s]

を定義すると, 群 $n$ のエレベータが通勤時間帯にビル内を往復する 回数は $T / \tau_{n}$ [回]と表される.よってエレベー夕群 $n$ の単位面積通 路が通勤時間帯に通過させることができる人数 $c_{n}\left[\right.$ 人 $\left./ \mathrm{m}^{2}\right]$ は次の如 くに記述できる：

$$
c_{n}=\frac{\lambda T}{\tau_{n}}
$$

$(1 \leq n \leq N)$

更に群 $n$ のエレベータがビル内を往復する所要時間 $\tau_{n}$ [s]を記述 するため

$$
\begin{aligned}
& v_{L}=(\text { 輸送を行なうソーン内でのエレベータの速度 }) \\
& v_{E}=(\text { 輸送を行なわないソーン内でのエレベータの速度) }
\end{aligned}
$$

を定義する，本研究では輸送を行なうソーン内と輸送を行なわない ソーン内とでエレベータの速度が異なるものと想定するにれらの 速度の間には必然的に $v_{L}<v_{E}$ の関係が成立する). このとき群 $n$ の エレベータがビル内を往復する所要時間 $\tau_{n}$ [s]は次の如くに記述で きる(図 4 参照) :

$$
\tau_{n}=2\left(\frac{h_{n}}{v_{L}}+\frac{H-\sum_{k=1}^{n} h_{k}}{v_{E}}\right) \quad(1 \leq n \leq N) .
$$

(6)式, (7)式よりエレベータ群 $n$ の単位面稙通路が通勤時間帯に通 過させることができる人数 $c_{n}\left[\right.$ 人 $\left./ \mathrm{m}^{2}\right]$ は次の如くに記述できる：

$$
c_{n}=\frac{\lambda T}{2\left(\frac{h_{n}}{v_{L}}+\frac{H-\sum_{k=1}^{n} h_{k}}{v_{E}}\right)} \quad(1 \leq n \leq N) .
$$

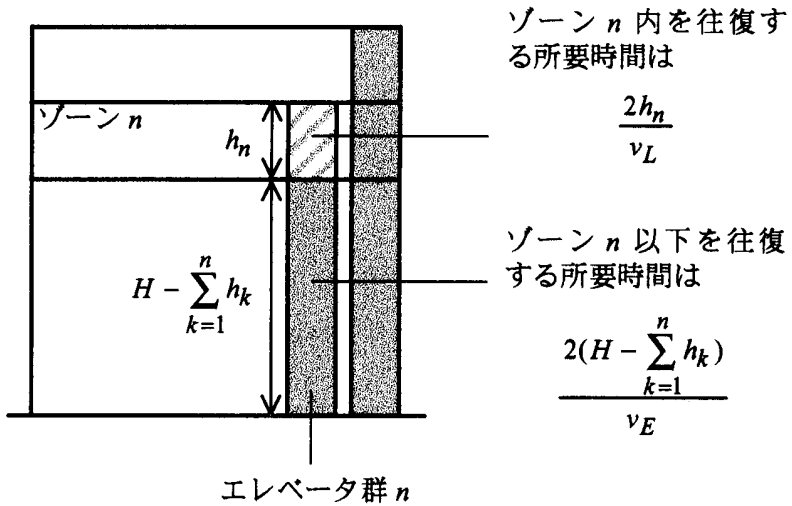

図 4 群 $n$ のエレベータがビル内を往復する所要時間.

\section{3. 最適なエレベータバンク権成}

本章では，作成したモデルおいてビルの高さを与え，ビルの有 効容積を最大化するエレベータバンク構成を追求する.

\section{1 ビルの有効容䖽の最大化問題}

(5)式と(8)式から与えられるビルの有効容稹 $V\left[\mathrm{~m}^{3}\right]$ は, ソーンの高 さ $h_{1}[\mathrm{~m}], h_{2}[\mathrm{~m}], \cdots, h_{N}[\mathrm{~m}]$ を変数に持つ $N$ 変数関数である.こ こでビルの有効容積を最大化する問題 $(\mathrm{P} 1)$ を次の如くに定義する :

(P1) maximize $\quad V\left(h_{1}, h_{2}, \cdots, h_{N}\right)$

$$
\begin{array}{ll}
\text { s.t. } & \sum_{n=1}^{N} h_{n}=H, \\
& h_{1} \geq 0, \quad h_{2} \geq 0, \cdots, h_{N} \geq 0 .
\end{array}
$$

この問題は即ち, ビルの高さ $H[\mathrm{~m}]$ ならびにビルのソーン数 $N$ が 与えられたとき, ビルの有効容積を最大化するソーンの高さ $h_{1}[\mathrm{~m}]$, $h_{2}[\mathrm{~m}], \cdots, h_{N}[\mathrm{~m}]$ を求める問題である. 制約条件はソーンの高さ の総和がビルの高さと一致すること((1)式), そして各々のソーンの 高さが非負の値をとることである.

更に(P1)の最適解を

$$
\begin{aligned}
\hat{h}_{n}= & =\text { (ビルの有効容積を最大化するソーンの高さ })[\mathrm{m}], \\
\hat{L}_{n}= & \text { (最適解の下でのソーン } n \text { のエレベータ通路面積 }) \\
& {\left[\mathrm{m}^{2}\right], } \\
\hat{V}_{n} & =\text { (最適解の下でのソーン } n \text { の有効容積 })\left[\mathrm{m}^{3}\right], \\
\hat{V} & =\text { (最適解の下でのビルの有効容皘 })\left[\mathrm{m}^{3}\right]
\end{aligned}
$$

とする. 最適解 $\hat{h}_{n}$ [m]が求まれば, ソーン $n$ のエレベー夕通路面積 $\hat{L}_{n}\left[\mathrm{~m}^{2}\right]$ ならびにエレベータ群 $n$ の通路面積 $\hat{L}_{n}-\hat{L}_{n-1}\left[\mathrm{~m}^{2}\right]$ を(3)式と (8)式から直ちに算出できる. 同様にソーン $n$ の有効容皘 $\hat{V}_{n}\left[\mathrm{~m}^{3}\right]$ を (4)式と(8)式から, ビルの有効容積 $\hat{V}\left[\mathrm{~m}^{3}\right]$ を(5)式と(8)式から直ちに 算出できる。 


\section{2 パラメータの值}

最大化問題(P1)を解析的に解くことは困難であるため, 本研究で はこれに逐次二次計画法[5]を適用した. パラメータの值は特に指定 しない限りは次の如くに設定した：

$\begin{array}{rlrl}\lambda & =2.0 & \text { 人 } / \mathrm{m}^{2}, \\ \rho & =0.025 & \text { 人 } / \mathrm{m}^{3}, \\ v_{L} & =0.70 & \mathrm{~m} / \mathrm{s}, \\ v_{E} & =3.50 \mathrm{~m} / \mathrm{s}, \\ T & =3600 & \mathrm{~s} .\end{array}$

オフィスビルにおける実際の計測によれば, 定員が 24 人であるエ レベータの外壁も含めた占有面積は $12 \mathrm{~m}^{2}$ 程度である. 従って単位面 積のエレベー夕通路に乗車できる人数を $\lambda=24 \div 12=2.0$ 人 $/ \mathrm{m}^{2}$ と設 定した. また文献[6]の p.63によれば，オフィスにおける就業者一人 当たりの占有面積は $10 \mathrm{~m}^{2} /$ 人程度である. ビルの階高が $4 \mathrm{~m}$ であると 考えれば就業者一人当たりの占有体積は $10 \times 4=40 \mathrm{~m}^{3} /$ 人である. 従 ってビルの就業者密度を $\rho=40^{-1}=0.025$ 人 $/ \mathrm{m}^{3}$ と設定した. エレべ 一夕の速度 $v_{L}[\mathrm{~m} / \mathrm{s}]$ ならびに $v_{E}[\mathrm{~m} / \mathrm{s}]$ の值はオフィスビルにおける 実際の計測に基づいて設定した(新宿センタービルと新宿三井ビル で計測した)。通勤時間帯 $T$ [s]の值は就業者の通勤の現状を考慮し 1 時間と設定した.

ところで(5)式と(8)式からわかるように, 最適解 $\hat{h}_{n}[\mathrm{~m}]$ はビルの底 面積 $S\left[\mathrm{~m}^{2}\right]$ によず決定される，従ってビルの底面積 $S\left[\mathrm{~m}^{2}\right]$ の值は 必要に応じて便宜的に設定する.

\section{3 最適なエレベータバンク權成と現実例}

ビルの高さが $H=219.3 \mathrm{~m}$,ゾーン数が $N=4$ であるときの最適な エレベータバンク構成を表 1 に示す.このビルの設定は新宿セン夕 一ビルを模している.よってビルの底面皘 $S\left[\mathrm{~m}^{2}\right]$ の值は $2650 \mathrm{~m}^{2}$ と設 定した(新宿センタービルの底面積).

\section{表 1 最適なエレベータバンク權成.}

\begin{tabular}{|c|c|c|c|c|}
\hline \\
\hline \multicolumn{3}{|c|}{ 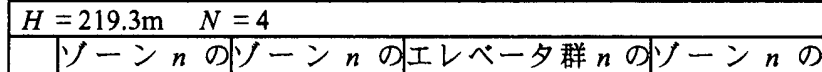 } & & \\
\hline$n$ & $\hat{h}_{n}[\mathrm{~m}]$ & $\begin{array}{l}100 \times \\
\hat{L}_{n} / S[\%]\end{array}$ & $\begin{array}{l}100 \times \\
\left(\hat{L}_{n}-\hat{L}_{n-1}\right) / S[\%]\end{array}$ & $\hat{V}_{n}\left[\mathrm{~m}^{3}\right]$ \\
\hline 1 & 43.8 & 3.31 & 3.31 & 112228.08 \\
\hline 2 & 48.9 & 6.67 & 3.36 & 120941.68 \\
\hline 3 & 56.5 & 10.21 & 3.54 & 134438.08 \\
\hline 4 & 70.1 & 14.39 & 4.18 & 159033.42 \\
\hline ビ & 有効容積 & $100 \times \hat{V} /$ & $0][1 / 0]$ & 90.61 \\
\hline
\end{tabular}

新宿センタービルのエレベータバンク構成を表 2 に示す. 当ビル は高さ $H=219.3 \mathrm{~m}$, 底面積 $S=2650 \mathrm{~m}^{2}$ の直方体であるとみなすこ とができ，また輸送に関して 4 つのソーンに分割されている．当ビ ルのデータについてであるが, ビルの高さ $H[\mathrm{~m}]$, ソーン $n$ の高さ $h_{n}[\mathrm{~m}]$, そしてソーン $n$ の通路面積 $L_{n}$ については実際に計測した

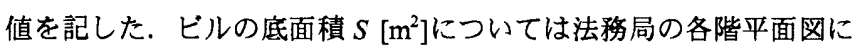
記載されている値を引用した。
表 2 新宿センタービルのエレベータバンク權成.

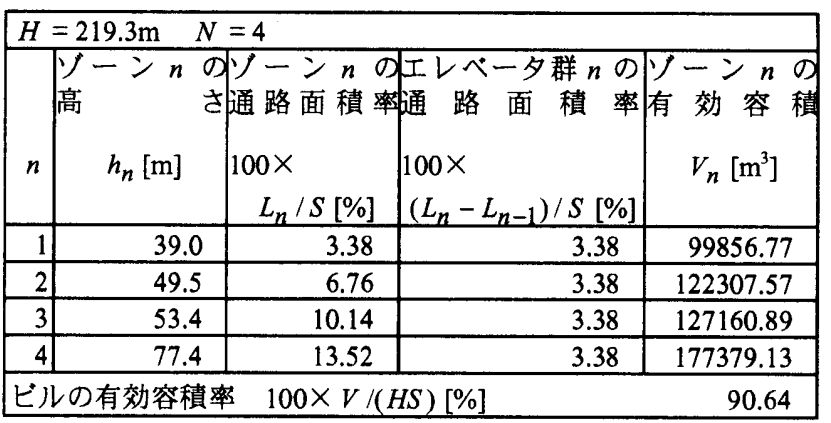

表 2 から，新宿センタービルでは地上に近いソーンほどソーンの 高さが高くなっていることが読み取れる．即ち

$$
h_{1}<h_{2}<h_{3}<h_{4}
$$

なる関倸が成立している，この傾向は，新宿三井ビルや新宿住友ビ ルをはじめ多くの高層オフィスビルでも見ることができ，更に作成 したモデルにより得られた結果(表 1 参照)とも一致している.

同じく表 2 から, 新宿センタービルではエレベータ群 $n$ の通路面 積率 $100 \times\left(L_{n}-L_{n-1}\right) / S$ [\%]がどのエレベータ群でも $3.38 \%$ と等し くなっていることが読み取れる.これはエレベー夕群を構成するエ レベータの台数がどのエレベータ群でも等しくなっているためであ り，このようなエレベータバンク構成は多くの高層オフィスビルで 見ることができる，一方モデルより得られた結果(表 1 参照)にお いても, エレベー夕群 $n$ の通路面積率 $100 \times\left(\hat{L}_{n}-\hat{L}_{n-1}\right) / S$ [\%]の值 には大差が無いように見える(3.31\%〜4.18\%)，このことは，現実の 高層オフィスビルの各エレベータ群のエレベータ台数が一定である ことの妥当性を, 本モテルの立場から担保するものと解粕できる. 即ち有効容積の確保に適したエレベータバンク構成法なのである.

但し，モテルにより得られた結果においては，僅かの差ではある が地上に近いソーンに輸送を行なうエレベータ群ほど通路面積率が 高くなっていることも否めない．即ちエレベータ群の通路面積の間 には

$$
\hat{L}_{1}<\hat{L}_{2}-\hat{L}_{1}<\cdots<\hat{L}_{N}-\hat{L}_{N-1}
$$

なる関倸が成立している，高層オフィスビルのエレベータバンク構 成を決定する際には，地上に近いゾーンに輸送を行なうエレべータ 群の通路面積を広くする, 即ちエレベータの台数を増やすべきであ ることが示唆される.

\section{4 ビルのソーン数とビルの有効容程率}

ビルのソーン数 $N$ の值を変化させて最大化問題 $(\mathrm{P} 1)$ を解き, 最適 解 $\hat{h}_{n}[\mathrm{~m}]$ の下でのビルの有効容積率 $100 \times \hat{V} /(H S)$ [\%]を求めた(ビ ルの高さを $H=200 \mathrm{~m}$ と与えた). その結果を図 5 に示す. 図 5 から ビルを輸送に関して多くのソーンに分割すればビルの有効容積率は 高くなることが読み取れる. 即ち、ソーニングによりビルの有効容 積を確保できることが示された。 


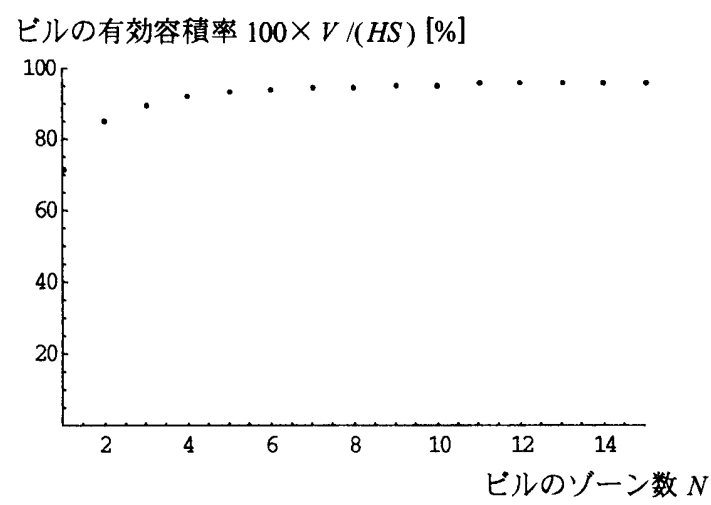

図 5 ビルのソーン数とビルの有効容积率.

しかしビルを輸送に関して多くのゾーンに分割すると，各ゾーン のエレベー夕通路面積は減少するが，エレベー夕を設置するにはあ る程度の面積が必要であるためビルの分割には限界が存在すること を忘れてはならない。

一方実在する高層オフィスビルの有効容積率の例として, 高さが $200 \mathrm{~m}$ 程度であるビルの有効容積率 $100 \times V /(H S)$ [\%]を表 3 に示す. これらの值は，実䟢の計測と法務局の各階平面図によるデータから 算出したものである. 表 3 から,ゾーン数が多いビルほどビルの有 効容積率が高くなっていることが読み取れ，モテルにより得られた 結果(図 5 参照)と一致していることがわかる.

表 3 高層オフィスビルの有効容㮴率.

\begin{tabular}{|c|c|c|c|c|}
\hline 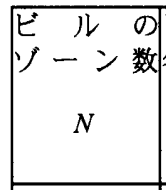 & 代 & $\begin{array}{l}\text { の|ビ } \\
\text { 称高 } \\
\\
H[\mathrm{~m}]\end{array}$ & $\left\{\begin{array}{ccc}\text { UE } & \text { ル } \\
& S\left[\mathrm{~m}^{2}\right]\end{array}\right.$ & $\begin{array}{l}\text { U゙ ル } \\
\text { 效容皘 } \\
100 \times \\
V / H S[\%]\end{array}$ \\
\hline 4 & $\begin{array}{l}\text { 新宿センタービル } \\
\text { 断宿三井ビル }\end{array}$ & $\begin{array}{l}219.3 \\
221.3\end{array}$ & $\begin{array}{l}2650 \\
2500\end{array}$ & $\begin{array}{r}90.64 \\
90.38\end{array}$ \\
\hline 6 & 新宿野村ビル & 194.7 & 1650 & 90.97 \\
\hline 7 & 新宿住友ビル & 205.1 & 2700 & 93.54 \\
\hline
\end{tabular}

\section{5 まとめ}

通勤時間帯に就業者の輸送を完了させることを前提とした本モテ ルにより示された最適な(ビルの有効容積を最大化する)エレベータ バンク構成は, 実在する高層オフィスビルにおけるそれと非常に類 似するものであった．現状のエレベータバンク構成はビルの有効容 積の確保に適していると言えよう．現実のビル設計におけるエレべ 一タバンク構成は, 膨大なシミュレーションに基いて㷌納的に行な われているものと思われる. すなわち本研究の意義は, 数理計画的 モデルによる演繹操作によっても，それとほぼ同様な結果が得られ ることを明示した点にある.

\section{4. ビルの有効容積を最大化するビルの高さ}

本章では，作成したモテルにおいてビルの有効容積を最大化する ビルの高さを追求する.

\section{1 ビルの高さとビルの有効容程}

ビルの高さ $H[\mathrm{~m}]$ の值を变化させて最大化問題(P1)を解き，最適 解 $\hat{h}_{n}[\mathrm{~m}]$ の下でのビルの有効容積 $\hat{V}\left[\mathrm{~m}^{3}\right]$ を求めた(ビルのソーン数 は $N=2,4,6$ と与え, ビルの底面積は $S=1 \mathrm{~m}^{2}$ と設定した). その 結果を図 6に示す。さらに

\section{$H^{*} \quad=\left(\right.$ ビルの有効容積 $\hat{V}\left[\mathrm{~m}^{3}\right]$ を最大化するビルの高さ $)[\mathrm{m}]$}

を定義する．図6 から，ビルを過度に高層化していくとビルの有効 容積は減少してしまうという著しい特徽が読み取れる，オフィスビ ルの高層化には限界が存在することが示されたのである.

またビルを輸送に関して多くのソーンに分割するならば，ビルの 高層化が勃果的であることが読み取れる，3.4 節で述べたようにビ ルを輸送に関して多くのゾーンに分割すればビルの有効容皘を確保 できるため, ビルの高層化が可能となるのである. しかし同じく 3.4 節で述べたようにビルを輸送に関して分割することには限界が存在 することも忘れてはならない.

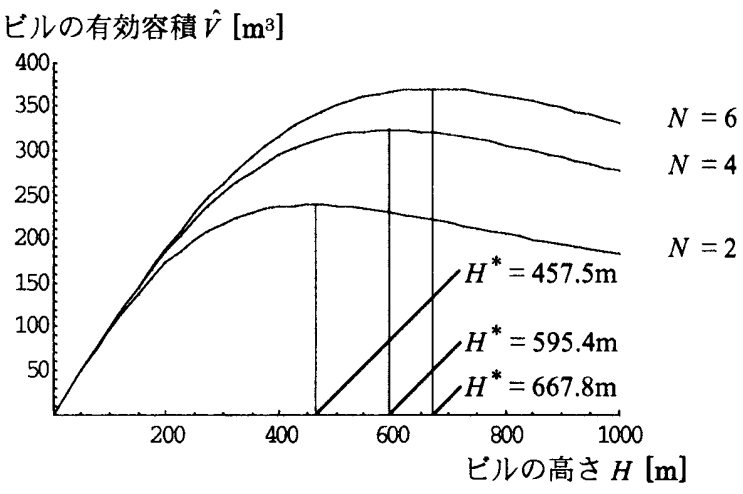

图 6 ビルの高さとビルの有効容程

\section{2 まとめ}

エレベータの輸送力を考慮した本モテルにより得られた，ビルを 過度に高層化していくとビルの有効容積が減少してしまうという結 果は，奥平[1]による従来の結果よりも更に暗い見通しである. オフ イスビルには就業者を速やかに通過させることができるだけのエレ ベー夕通路が必要不可欠である. またソ一ニングによりビルの有効 容積を確保できるが，ビルを輸送に関して多くのソーンに分割する ことにも限界が存在する.こういった構造上, オフィスビルの高層 化には限界が存在するということを本モデルは示唆していると言え よう.

\section{5. ビルを建設することによる利澗を最大化するビルの高さ}

本章では，作成したモデルにおいてビルを建設することによる利 潤を最大化するビルの高さを追求する，以下では，自社ビルを建設 するケース(5.1 節)と貸貸オフィスビルを建設するケース(5.2 節)に 場合分けして記述する. 


\section{1 企羍が用地を取得し自社ビルを建設するケース}

\section{1 .1 就莱者一人当たりのコスト}

企業が用地を取得し自社ビルを建設するケースを想定し，就業者 一人当たりの建設コストの最小化問題を定式化する.

就業者一人当たりのコストを記述するため

$$
\begin{array}{ll}
a & =\text { (地価) }\left[\mathrm{H} / \mathrm{m}^{2}\right], \\
b & =\text { (ビルの単位容積当たりの建設費 })\left[\mathrm{P} / \mathrm{m}^{3}\right]
\end{array}
$$

を定義する．そしてビルの建設に要するコスト P [円]を

$$
P=a S+b H S=(a+b H) S
$$

と記述する(即ち用地の取得費 $a S$ [円]とビルの建設費 $b H S$ [円]との 和). 実際にこれらの費用は, ビルの建設に要するコストの大半を占 める．更にビルに居住できる就業者数 $W$ [人]はビルの就業者密度 $\rho\left[\right.$ 人 $\left./ \mathrm{m}^{3}\right]$ とビルの有効容積 $V\left[\mathrm{~m}^{3}\right]$ との積で

$$
W=\rho V
$$

と記述できる. 以上より就業者一人当たりのコスト $\Phi$ [円/人]は次の 如くに記述できる :

$$
\begin{aligned}
\boldsymbol{\Phi} & =\frac{P}{W}=\frac{(a+b H) S}{\rho V} \\
& =\frac{a+b \sum_{n=1}^{N} h_{n}}{\rho \sum_{n=1}^{N} h_{n} \prod_{k=1}^{n} \frac{c_{k}}{\rho h_{k}+c_{k}}}
\end{aligned}
$$

\section{1 .2 就業者一人当たりのコストを最小化する問題} 就業者一人当たりのコストを最小化する問題(P2)を

$$
\begin{array}{ll}
\operatorname{minimize} & \Phi\left(h_{1}, h_{2}, \cdots, h_{N}\right) \\
\text { s.t. } & \sum_{n=1}^{N} h_{n}=H, \\
& h_{1} \geq 0, h_{2} \geq 0, \cdots, h_{N} \geq 0
\end{array}
$$

と定義し，更に

$\hat{\boldsymbol{\Phi}}=\left(\right.$ 最適解 $\hat{h}_{n}[\mathrm{~m}]$ の下での就業者一人当たりのコスト) [円/人]

を定義する．この問題(P2)は即ち，ビルの高さ $H[\mathrm{~m}]$ ならびにビル のソーン数 $N$ が与えられたときに就業者一人当たりのコストを最 小化する各ソーンの高さ $h_{\mathrm{I}}[\mathrm{m}], h_{2}[\mathrm{~m}], \cdots, h_{N}[\mathrm{~m}]$ を求める問題 である.ところが(13)式からわかるように就業者一人当たりのコス トを最小化するためにはビルの有効容積を最大化すればよいことが 自明である.したがって，結局この問題の解は 3.3 節で求めた最適 解 $\hat{h}_{n}[\mathrm{~m}]$ と一致する。

\section{1 .3 パラメータの值}

パラメータの值は特に指定しない限りは次の如くに設定した：

$a=1248000$ 円 $/ \mathrm{m}^{2}$,

$b=97500 \mathrm{円} / \mathrm{m}^{3}$.

文献[7]の pp.254-255 では六本木に建設される山王共同ビル(仮 称，西暦 2000 年施工予定)の事業収支モデルが構築されているが， 路線価は 1248000 円 $/ \mathrm{m}^{2}$ (4160000 円/坪), ビルの建築費は 390000 円 $/ \mathrm{m}^{2}(1300000$ 円/坪)とされている. 本研究でも地価が高い地域にオフ イスビルを建設することを想定し, 地価を $a=1248000$ 円 $/ \mathrm{m}^{2}$ と設定 した. 更にビルの階高が $4 \mathrm{~m}$ であると考えビルの単位容積当たりの 建設費を $b=390000 \div 4=97500 \mathrm{H} / \mathrm{m}^{3}$ と設定した。

\section{1 .4 ビルの高さと就業者一人当たりのコスト}

ビルの高さ $H[\mathrm{~m}]$ の值を変化させて最小化問題(P2)を解き, 最適 解 $\hat{h}_{n}[\mathrm{~m}]$ の下での就業者一人当たりのコスト $\hat{\boldsymbol{\Phi}}$ [円/人]を求めた(ビ ルのソーン数は $N=2,4,6$ と与えた). その結果を図 7 に示す. 更 に

$$
\begin{aligned}
H^{* *}= & (\text { 就業者一人当たりのコスト } \hat{\Phi}[\text { 円/人 }] \text { を最小化する } \\
& \text { ビルの高さ })[\mathrm{m}]
\end{aligned}
$$

を定義する，図７から，ビルを輸送に関して多くのゾーンに分割す れば就業者一人当たりのコストは小さくなることが読み取れる.ソ 一ニングにより企業の利閌を追求できることが示されたと言える.

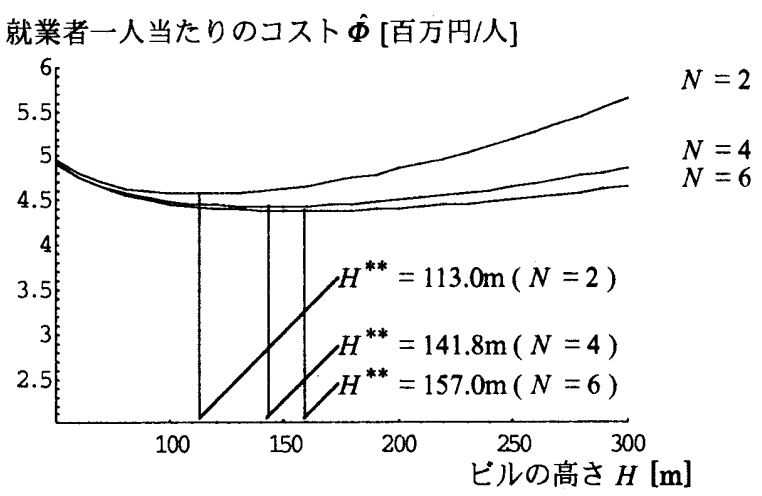

図 7 ビルの高さと就業者一人当たりのコスト.

\subsection{5 地価と就業者一人当たりのコストを最小化するビルの高さ} 地価 $a\left[円 / \mathrm{m}^{2}\right]$ の值を連続的に変化させて, 就業者一人当たりのコ ストを最小化するビルの高さ $H^{* *}[\mathrm{~m}]$ 求めた(ビルのソーン数は $N=2 ， 4 ， 6$ と与えた)，その結果を図 8 に示す. 図 8 から地価が 高ければビルの高層化が経済的であることが読み取れる．企業が地 価の高い地域に用地を取得し自社ビルを建設するケースでは, 容䅡 率規制の限度まで高層化されるのが常である。ここでの結果は，こ のことに対する(簡便な数理計画モデルの立場からの)一つの説明原 理と言えよう。 


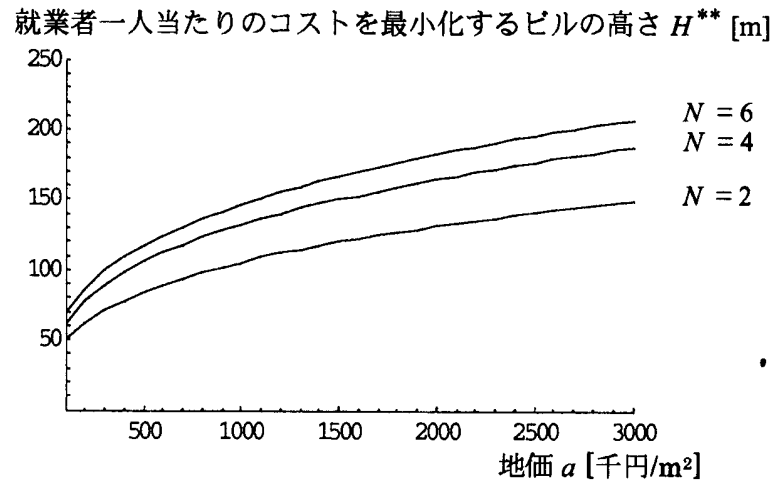

图 8 地価と就羍者一人当たりのコストを最小化するビルの高さ

\section{2 ティベロッパーが自己所有地に賃貸オフィスビルを建眨する ケース}

5.2.1 ティィベロッパーの利閏

ティペロッパーの利潤を記述するため

$$
\begin{aligned}
p & =\text { (ビルの貸室賃料) [円 } / \mathrm{m}^{3} \cdot \text { 月] }, \\
m & =\text { (ビルの耐用期間) [月], } \\
I & =\text { (ティベロッパーの収入) [円], } \\
C & =\text { (ティベロッパーの支出 } \text { [円], } \\
B & =\text { (ティベロッパーの利閏) [円] }
\end{aligned}
$$

を定義する．なお，上記の $p\left[\right.$ 円 $/ \mathrm{m}^{3} \cdot$ 月]にビルの階高を乗ずれば， ビルの平米・月当たりの貢料となることは言うまでもない. 即ち,こ こでは専有床面積に比例して筫料が課せられると想定していること に他ならない. そしてティベロッパーの収入 $I$ [円]を，ビルの耐用 期間分の貸室貨料 $m p\left[\mathrm{H} / \mathrm{m}^{3}\right]$ とビルの有効容積 $V\left[\mathrm{~m}^{3}\right]$ との積で

$$
I=m p V
$$

と記述する. 即ち，賃貸オフィスビルの入居率が常に $100 \%$ ある と想定し，また利息は考慮しないことにする．更にティベロッパー の支出 $C$ [円]を

$$
C=b H S
$$

と記述する.すなわちビルの建設費 $b H S$ [円]のみで与えることにす る. 以上より，ティベロッパーの利潤 $B$ [円]は次の如くに記述でき る :

$$
\begin{aligned}
& B=I-C=m p V-b H S \\
&=\left(m p \sum_{n=1}^{N} h_{n} \prod_{k=1}^{n} \frac{c_{k}}{\rho h_{k}+c_{k}}-b \sum_{n=1}^{N} h_{n}\right) S \\
&(\because(1),(5)) .
\end{aligned}
$$

\subsection{2 ティベロッパーの利澗を最大化する問題}

ティベロッパーの利潤を最大化する問題(P3)を
(P3) $\quad$ maximize $\quad B\left(h_{1}, h_{2}, \cdots, h_{N}\right)$

$$
\begin{array}{ll}
\text { s.t. } & \sum_{n=1}^{N} h_{n}=H, \\
& h_{1} \geq 0, \quad h_{2} \geq 0, \cdots, \quad h_{N} \geq 0
\end{array}
$$

と定義し，更に

$$
\hat{B}=\left(\text { 最適解 } \hat{h}_{n}[\mathrm{~m}] \text { の下でのティベロッパーの利潤 }\right) \text { [円] }
$$

を定義する.この問題は即ち，ビルの高さ $H[\mathrm{~m}]$ ならびにビルのソ 一ン数 $N$ が与えられたとき,ティベロッパーの利閏を最大化するソ ーンの高さ $h_{1}[\mathrm{~m}], h_{2}[\mathrm{~m}], \cdots, h_{N}[\mathrm{~m}]$ 求める問題である. とこ ろが(16)式からわかるように，ティベロッパーの利潤を最大化する ためにはビルの有効容積を最大化すればよいのだから, 結局この問 題の解は 3.3 節で求めた最適解 $\hat{h}_{n}[\mathrm{~m}]$ と一致する.

\subsection{3 パラメータの㑮}

パラメータの值は特に指定しない限りは次の如くに設定した :

$$
\begin{aligned}
& p=1875 \mathrm{円} / \mathrm{m}^{3} \cdot \text { 月 }, \\
& m=600 \text { ヶ月. }
\end{aligned}
$$

前出の文献[7]における山王共同ビルの場合, ビルの単位床面積当 たりの貸室貨料が 7500 円 $/ \mathrm{m}^{2}$ ·月(25000 円/坪・月)とされている. 本 研究ではビルの階高が $4 \mathrm{~m}$ であると考え, ビルの貸室貨料を $p=$ $7500 \div 4=1875$ 円 $/ \mathrm{m}^{3}$. 月と設定した. また文献[8]の p.351 によれば, 鉄筋コンクリート造の事務所の法定耐用年数は 50 年である.よって ビルの耐用期間を $m=50 \times 12=600$ ケ月と設定した.

\subsection{4 ビルの高さとティィベロッパーの利澗}

ビルの高さ $H[\mathrm{~m}]$ の值を変化させて最大化問題(P3)を解き, 最適 解 $\hat{h}_{n}[\mathrm{~m}]$ の下でのディベロッパーの利潤 $\hat{B}$ [円]を求めた(ビルのソ 一ン数は $N=2,4,6$ と与え, ビルの底面積は $S=1 \mathrm{~m}^{2}$ と設定した). その結果を図 9 に示す，更に

$$
\begin{aligned}
H^{* * *}= & (\text { ディベロッパーの利潤 } \hat{B}[\text { 円]を最大化するビルの } \\
& \text { 高さ }[\mathrm{m}]
\end{aligned}
$$

を定義する.

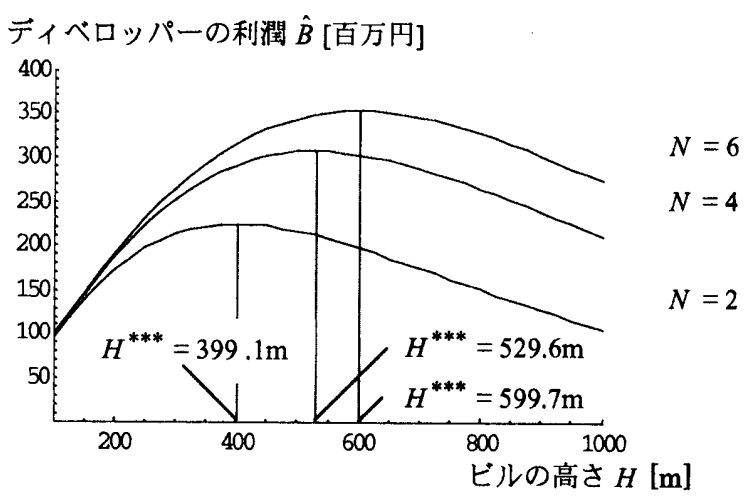

図 9 ビルの高さとディベロッパーの利閩. 


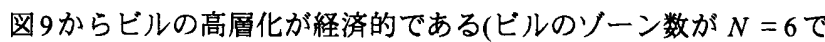
あるときを例にとればディベロッパーの利潤を最大化するビルの高 さは $H^{* * *}=599.7 \mathrm{~m}$ である)ことが読み取れる. ティベロッパーが貨 貸オフィスビルを建設するケースでは，オフィスビルの高層化が経 済的な必然である.

またビルを輸送に関して多くのソーンに分割すれば，ディべロッ パーの利潤は増加することも読み取れる、ソーニングによりティべ ロッパーの利潤を追求できることが明示されたと言える.

\section{3 エレベータの速度と利潤を最大化するビルの高さ}

エレベータの平均速度 $v_{E}[\mathrm{~m} / \mathrm{s}]$ の值を変化させて, 就業者一人当 たりのコストを最小化するビルの高さ $H^{* *}[\mathrm{~m}]$ ならびにディべロッ パーの利潤を最大化するビルの高さ $H^{* * *}[\mathrm{~m}]$ を求めた(ビルのソー ン数は $N=4$ と与えた). その結果を図 10 に示す. 図 10 から, エレ ベータが高性能であればビルの高層化が経済的であることが読み取 れる. 言い換えれば，ビルを高層化し利潤を追求するためには高性 能のエレベータが不可欠であることが示されたのである．大手のメ 一カーがエレベータの性能向上に取り組んできた理由もうかがえよ う。しかし移動の快適性を考慮するとエレベータの性能向上には限 界が存在することを忘れてはならない。

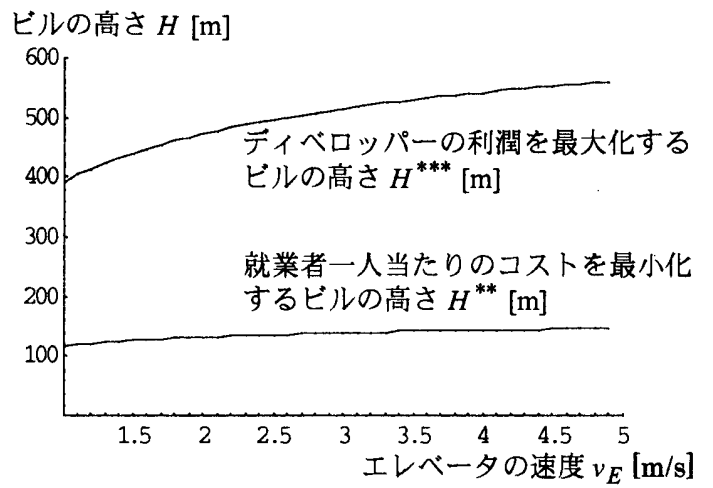

図 10 エレベータの速度と利洞を最大化するビルの高さ.

\section{4 オフィスビル高首化の限界}

(13)式からわかるように，就業者一人当たりのコスト $\Phi[$ 円/人]は ビルの有効容積 $V\left[\mathrm{~m}^{3}\right]$ に関する減少関数である．即ちビルの有効容 積を最大化するビルの高さ $H^{*}[\mathrm{~m}]$ を超えてビルを高層化していく と, ビルの有効容積は減少に転じ就業者一人当たりのコストは増加 してしまう.よってビルの有効容積を最大化するビルの高さ $H^{*}[\mathrm{~m}]$ と就業者一人当たりのコストを最小化するビルの高さ $H^{* *}[\mathrm{~m}]$ との 間には，地価ならびにビルの建設費の值によらず必然的に次の関係 が成立する。

$$
H^{* *} \leq H^{*}
$$

同じく(16)式からわかるように，ティベロッパーの賃貸ビルから の利潤 $B$ [円]はビルの有効容積 $V\left[\mathrm{~m}^{3}\right]$ に関する増加関数である. 即 ちビルの有効容積を最大化するビルの高さ $H^{*}[\mathrm{~m}]$ を超えてビルを 高層化していくと，ビルの有効容積は減少に転じティベロッパーの 利潤は隇少してしまう。よってビルの有効容積を最大化するビルの
高さ $H^{*}[\mathrm{~m}]$ とディベロッパーの利潤を最大化するビルの高さ $H^{* * *}[\mathrm{~m}]$ との間には, ビルの建設費ならびにビルの貸室賃料の值に よらず必然的に次の関係が成立する.

$$
H^{* * *} \leq H^{*}
$$

4.1 節で述べたように, ビルを過度に高層化していくとビルの有 効容積が減少してしまう以上，ビルを高層化し利潤を追求すること にも限界が存在するのである。

\section{5 まとめ}

本モデルにより，オフィスビルの高層化が経済的な必然であるこ とが示された. 表 3 に示したように新宿には $200 \mathrm{~m}$ を超える高層才 フィスビルが多く建ち並ぶが，これは利潤追求の理に適っていると 言えよう.しかしオフィスビルを高層化し利潤を追求することには 限界が存在することも同時に示されたのである.

\section{6. おわりに}

本研究で得られた結果は，エレベータの運行ならびにビルへの就 業者の到着に関して膨大・緻密なシミュレーションを行ない得られ たものではない．しかし高層オフィスビルにおける輸送の骨格のみ から作成した簡略な数理計画モテルからも，理論的な裏付けの下に オフィスビルの高さ, そしてエレベー夕構成を評価できる可能性を 示すことができた.ここに本研究の意義がある.

また本研究では, エレベータが如何なる設置面積をもとりうると 想定しており，この点では若干現実から乘離している，現状のエレ ベータ構成のように, エレベータ群の通路面積がどのエレベー夕群 でも等しくなっているとして本モテルを再構成することは, 今後の 課題としたい.

\section{爵辞}

事業収支モデルに関する有益な文献をこ紹介下さった高田 誠氏(株式会 社フジタ・環境創造事業本部)に謝意を表します、本研究は文部科学省科学研 究費基盤研究(B)(1)「都市の施設配置および交通に関する数理的並びに定量的 研究」(課題番号：11480091)の㭪助を受けました。研究代表者の伏見正則教授 (南山大学)をはじめとするメンバーの先生方にお礼申し上げます.最後になり ましたが，エレベータの尃閒用語や表現の適切性等に関して想切かつ貴重な るコメントを下さった圈名の査読者に心より感謝致します.

\section{参考文献}

[1]奥平耕造 : 都市工学読本(彰国社, 1976).

[2]西日本工高建築連盟編 : 新建築設計ノート・オフィスビル(彰国 社, 1989).

[3]田口 東：超々高層ビルにおける内々交通とエレベータ面皘, Journal of the Operations Research Society of Japan, Vol.37, No.3, pp.232-242 (1994).

[4]田口 東: コンパクトな建物, 平成 9 年度 10 年度科学研究費補 助金(基盤研究(B)(1))研究成果報告書(1999).

[5]茨木俊秀・福島雅夫 : 最適化プログラミング(岩波書店, 1991), [6]建築単位の事典研究会編：建築単位の事典(彰国社, 1992).

[7]用途・業態 事業特性テータファイル(建築知識, 1996). [8]都市・建筑企画開発マニュアル(建築知識, 1999). 